\title{
USING LEUCAENA LEAF MEAL IN DOE RABBIT DIETS
}

Aboul-Ela, S.S. ${ }^{\star}$; K. Abd El-Galii** $;$ M. M. Soliman*; A.I. Attia* and

A.A. Abd El-Dayem **

* Poultry Dept. Fac. of Agric. Zagazig University, Zagazig, Egypt.

** Animal and Poultry Nutrition Dept., Desert Research Center, ElMatareya, Cairo, Egypt

\begin{abstract}
Twenty New Zealand white (NZW) rabbits doe of 6 months of age were randomly divided into four groups (5 does in each group). The first group was fed on the basal diet as control, while the other three groups were fed on diets containing either 15,20 or $25 \%$ Leucaena leaf meal (LLM),respectively. Chemical composition, digestibility coefficients, productive and reproductive performance were studied.

Results obtained could be summarized as follows :

Number of total kits born and number of kits born alive gradually decreased with increasing LLM in the diets from $0-25 \%$.Body weight change in does during gestation period due to incorporated LLM in the diets was tended to be in positive balance. While does body weight change during suckling period were tended to be in negative balance. Feed intake which includes feed consumption by pups before weaning, increased with increasing the level of LLM in their diets.

Milk yield on feeding levels 0,15 and20\% $(2.42,2.20$ and2.26 kg/doe) was not significantly different, but milk yield of does feeding levels $25 \% \mathrm{LLM}(1.91 \mathrm{~kg} / \mathrm{doe})$ were significant $(P<0.05)$ lower than other treatments or the control group.

Litter size, litter weight and litter weight gain at birth,21days and weaning age were generally tended to be lower $(P<0.05)$ with increasing LLM in the diets. Feed conversion ratio tended to be higher $(\mathrm{P}<0.05)$ by doe rabbits fed LLM diets compared with the control diet.

Increasing the dietary LLM resulted significant decrease in digestibility coefficients of DM,OM,CP,CF,NFE and feeding values expressed as DCP,TDN\% and $\mathrm{DE}(\mathrm{Kcal} / \mathrm{Kg})$. On the other hand EE digestibility was not affected by LLM addition.

Does fed a diet contained 20\%LLM decreased the cost of feed relatively to the selling price of total weaned pups and increased considerably the economical efficiency in comparison to the control and other treatment.

From the nutritional and economical efficiency points of view, the leucana leaf meal could be used up to $20 \%$ in pregnant and lactating rabbit does without deleterious effect on their performance.

Keywords: Rabbit does, productive and reproductive performance, digestion trials and economic efficiency.

\section{INTRODUCTION}

In Egypt, shortage of feedstuffs is one of the major limiting factors for increasing animal production, while there are large quantities of underutilized inexpensive feed resources available such, as Leucaena (leucocephala). Using of such non traditional feeds in animal feeding substantially participate in solving this problem, decreases the cost of feeding and hence the marketing price of animal products. Leucaena is the common name for leucaena leucocephala. It is considered a green legume used for animal
\end{abstract}


feeding in tropical and subtropical. It has a high content of protein, gives high yield of green plant and bears different environmental circumstances.

A depression in the performance of chicks was observed when LLM was included in diets at $5 \%$ level (D'Mello and Thomas, 1978). In contrast, other reports have indicated that LLM depressed the performance of chicks only at the higher inclusion rate of $20 \%$ (Meulen et al, 1984). On the other hand, Ghatneker et al.(1982) reported improved growth performance of tilapia fish with the inclusion of 25\% LLM in the diet. Abd EL-Galil.K;et al ;(2001) found that LLM could be used successfully and safety up to $15 \%$ of rabbit diets without adverse affect on rabbits.Ghazala,A.A;et al (1998) reported that it could be formulate diets for weanling rabbits to include either $15 \%$ dried Sesbania aegyptica (DSA) or $15 \%$ dried Leucaena leucocephala(DLL) as a partial substitution for alfalfa meal in the basal diet without any adverse effect on rabbits growth performance or any harmful influence on animal health and consequently the consumer.

There is little information in the literature with using LLM in feeding rabbits doe. Therefore, this study aimed to investigate the possibility of using different levels of LLM in feeding doe rabbits.

\section{MATERIALS AND METHODS}

The present experiment was carried out at Maryiout Experimental Research Station (South West of Alexandria) which belongs to the Desert Research Center, Egypt. At the beginning of the experiment, indirect digestibility trial was carried out to evaluate the digestibility coefficients and feeding value (as DE and TDN) of leucaena leaf meal .A basal ration was formulated from yellow corn grains $96 \%$, limestone $2 \%$, bone meal $1 \%$, salt $0.5 \%$, and per-mix $0.5 \%$, The tested ration leucaena leaf meal was formulated from LLM and the basal ration $25: 75 \%$ of weight. A cording to these results, diets were formulated Leucaena leaf meal was incorporated in the diets with four levels $(0,15,20$ or $25 \%)$. The experimental diets were nearly isonitrogenous, isofibrous and isocaloric and covered the requirements of doe rabbits at the lactating period as recommended by INRA(1984). The composition and chemical analysis of the experimental diets are shown in Table 1. The leucaena leaf meal were harvested from different areas in Alexandria. Samples of leucaena were taken from time to time, composited, milled and analyzed for their chemical constituents.

Twenty New Zealand white rabbits doe of six months of age with nearly equal body weight were used to investigate the possibility of using Leucanena leaf meal in diets for feeding doe rabbits. Rabbits were randomly divided into four treatment groups (five does in each group). All rabbits were kept under the same managerial, hygienic and environmental conditions. Doe rabbits were individually housed in wire cages and their offsprings were collectively raised in cages, in the same batteries, in a well ventilated building . Fresh water was automatically available all the time by stainless steel nipples fixed in each cage. At mating, does were individually transferred to the buck cages and returned to their own hutches after mating. All does were 
bred usually two days after kindling. They were palpated 10 days post-mating to be rebred until pregnancy was detected.Doe were weighted at the beginning (24weeks of age) and at the end (34 weeks of age).

Traits studied were doe live body weight $(\mathrm{g})$ at the beginning, after kindling and end of the experiment, gestation period, litter birth 21 and 35 days of age, litter and bunny weights at birth, 21 and 35 days of age and mortality rate of pups from birth to 21 and 35 days of age. The total feed consumed per each group(doe and litters) during the 70 days of the experimental period, cost of the total feed consumed per group and price of selling total weaned pups per each group during the experimental period, were also recorded.

Doe milk consumed by the pups from birth to 21 days of age was estimated by The following equation:

$\mathrm{Y}=($ Litter weight gain during the period $0-21$ day $(\mathrm{Kg})) / 0.56$

Where, $Y$ was the doe milk consumed by pups during the period 0-21 days of age, 0.56 was standard figure given by Cowie (1969) for the NZW strain,

Partridge and Allan( 1982) for crossbred does depending on the linear relationship between the litter weight gain $(\mathrm{kg})$ and doe milk consumed.

The feed conversion ratio (FCR) was calculated during the whole gestation and suckling period according to the following formula:

$\mathrm{FCR}=$ (Feed intake during gestation + Feed intake during suckling period)/(Total Litter gain).

Economical efficiency( EE) at weaning age of pups (35 days of age) was calculated according to the following equation:

$E E=[(A-B) / B] \times 100$

Where: $A$ was the selling price of the obtained pups at weaning age and $B$ was the feeding cost for producing these pups.

At the end of the experiment, four does from each treatment were used to determine the digestibility coefficients of the nutrients and to calculate the nutritive values of the experimental diets. Rabbits were housed in individual metabolism cages and fed the experimental diets for a period of seven days to allow the rabbits to become adjusted to cages. Then the faces were collected every 24 hours for seven consecutive days. Chemical analysis of LLM, the experimental diets and faces were carried out according to A.O.A.C. (1990). Tannin was assayed using method of Balbaa(1969). Neutral detergent fiber (NDF), acid detergent fiber (ADF) were analyzed according to Goering and Van Soest (1970).Nutritive values of LLM and experimental diets were calculated as digestible crude protein (DCP), total digestible nutrients (TDN) and digestible energy (DE). Digestible crude protein and total digestible nutrients were calculated according to Perez et al. (1995).While, The digestible energy values $(\mathrm{Kcal} / \mathrm{Kg})$ of the experimental diets and LLM were calculated according to the equation of Schieman et al. (1972) as follows:

$\mathrm{DE}(\mathrm{Kcal} / \mathrm{Kg})=5.28(\mathrm{DCP}, \mathrm{g} / \mathrm{Kg})+9.51(\mathrm{DE}, \mathrm{g} / \mathrm{Kg})+4.2(\mathrm{DCF}, \mathrm{g} / \mathrm{Kg})$ $+4.2(\mathrm{DNFE}, \mathrm{g} / \mathrm{Kg})$.

Where: DCP, DEE, DCF and DNFE = digestible CP, EE, CF and NFE, respectively. 


\section{RESULTS AND DISCUSSION}

\section{Chemical composition, digestion coefficients and nutritive value of leucaena leaf meal:}

The chemical composition and fiber fractions of LLM were 92.80, 84.10, 24.80,5.35,12.30, 41.65, 8.70, 38.80 and $21.50 \%$ for DM, OM, CP, EE, CF, NFE, Ash, NDF and ADF, respectively, while value of total tannin was $8.75 \%$, as shown in Table 2. These values are nearly similar to those reported by Abd El-Galil .K;et al (2001), while the values recorded for CP, EE. CF, NFE and ash were less and NDF and ADF were more than those obtained by Ghazala (1996). The variation of the chemical composition of LLM may be due to the differences between cultivars, climatic and soil conditions in different geographical locations. It is clear that LLM contains markedly high percentage of crude protein but lower NFE content, indicating that it has potential value as a source of protein for livestock as previously reported by Gupta et al. (1978).

Table 2: Chemical analysis, digestibility coefficients and nutritive values of leucaena leaf meal.

\begin{tabular}{lcc}
\hline Items & $\begin{array}{c}\text { Chemical composition \% } \\
\text { (as fed) }\end{array}$ & Digestibility coefficients \% \\
\hline & 92.80 & 77.15 \\
DM & 84.80 & 76.75 \\
OM & 24.80 & 72.45 \\
CP & 12.30 & 28.69 \\
CF & 5.35 & 71.0 \\
EE & 41.65 & 78.15 \\
NFE & 8.70 & - \\
Ash & 38.80 & - \\
NDF & 21.50 & - \\
ADF & 8.75 & \\
Total tannin & & 17.97 \\
Nutritive values (as fed): & & 62.30 \\
DCP\% & & 2426.00 \\
TDN\% & & \\
DE( Kcal / Kg) & &
\end{tabular}

Results in Table 2 showed that digestibility coefficients of nutrients in LLM were $77.15,76.75,72.45,28.69,71.0,78.15$, for DM, OM, CP, CF, EE, NFE, respectively. The nutritive values of LLM in the present study were $17.97 \%, 62.30 \%, 2426(\mathrm{kcal} / \mathrm{kg})$ for DCP,TDN and digestible energy, respectively.

\section{Productive and reproductive performance of does Gestation period}

The results obtained for gestation period are presented in Table 3. Dietary LLM level did not affect gestation length.

The daily feed intake (Table 3 ) of the does was gradually increased with increasing the LLM level in the diets from 0.0 up to $25 \%$. In comparison to the control daily feed intake of $15,20 \%$ and $25 \%$ LLM.contained groups was higher by about $0.77,1.43$ and $3.19 \%$,recpectively. 
Number of total kids born and number of total kids born alive gradually decreased with increasing LLM in the diets from 0 to $25 \%$. Results showed that the highest total number of kids born and those born alive was obtained by does fed diet without LLM $(0.0 \%)$,While the lowest was recorded for does fed diet containing $25 \%$ LLM. Body weight change in does during gestation period due to incorporated LLM in the diets was tended to be in positive balance. Some of these gains may be attributable to an increase in gut fill ( Parigi-Bini et. al .,1992). This may mean that the levels of nutrient used in the present study covered the nutrients requirements for development of fetus and placenta.

Table 3: Performance of does during gestation period as affected by dietary Leucaena leaf meal levels.

\begin{tabular}{|c|c|c|c|c|c|c|c|}
\hline $\begin{array}{l}\text { LLM } \\
\text { Level } \\
(\%)\end{array}$ & $\begin{array}{c}\text { Gestation } \\
\text { Length(days) }\end{array}$ & $\begin{array}{l}\text { Feed intake } \\
\text { (g/day/doe) }\end{array}$ & $\begin{array}{l}\text { Doesbody } \\
\text { at mating }\end{array}$ & $\begin{array}{l}\text { Weight(g) } \\
\text { at kindling }\end{array}$ & $\begin{array}{l}\text { Body weight } \\
\text { change(g) }\end{array}$ & $\begin{array}{l}\text { No of } \\
\text { total } \\
\text { kids } \\
\text { born }\end{array}$ & $\begin{array}{c}\text { No of } \\
\text { total kids } \\
\text { born } \\
\text { alive }\end{array}$ \\
\hline ontrol & & 154.9 & & & & 30 & 30 \\
\hline 15 & $30.50 \pm 0.20$ & $156.1 \pm 3.6^{b}$ & $2850.0 \pm 5$ & $2982 \pm 46.6$ & $+132.50 \pm 7.5$ & 29 & 29 \\
\hline 20 & & $157.15 \pm 0.8^{\mathrm{ab}}$ & $2860.2 \pm 5$ & $3000+60.2$ & $+139.80 \pm 5$ & 28 & 28 \\
\hline 25 & $30.75 \pm 0.24$ & $160.0 \pm 0.5^{\mathrm{a}}$ & $2885.0 \pm 5$ & $3015 \pm 53.7$ & $+130.50 \pm 12.2$ & 26 & 26 \\
\hline Sig. & NS & & $N \bar{S}$ & $\mathrm{NS}$ & $N S^{-}$ & & \\
\hline
\end{tabular}

$\overline{a, b}$, Means in the same column within each classification bearing different letteres, are significantly $(P<0.05)$ different.

${ }^{*} \mathrm{p}<0.05 \quad \mathrm{Ns}=$ not significant

\section{Suckling period}

Data presented in Table 4. showed that does body weight change during suckling period were tended to be in negative balance. The balance results depression in doe body weight was increased with increasing LLM in diets.

Our results agree with those obtained by Parigi-Bini et al(,1991) who found that does mobilize body tissue and loose body fat and body energy during lactation and consequently, showed a considerable reduction in empty body weight. Particularly, Raharjo et.al (1986) mentioned that mobilization of body tissue begins at about 11days following parturition and continues for remainder of the lactation period, results a rapid decrease in each of milk production after 21 days of lactation and feed intake at 28days ,Partridge and Allan,(1983).

Feed intake which includes feed consumption by pups before weaning, increased with increasing the level of LLM in the diets.

The differences in feed intake were significant $(P<0.05)$ between does fed 15,20 and $25 \%$ LLM and those fed 0.0 (control group) .It is clear that the highest feed intake (184.01g/doe/day) was obtained by does fed diet contained $25 \%$, while the lowest value was obtained for does fed diet without LLM.

Effect of feeding levels( 0,15 , and $20 \%$ )on milk yield were not significantly different, but yields of does feeding level $25 \%$ LLM $(1.91 \mathrm{~kg} / \mathrm{doe})$ were significantly $(\mathrm{P}<0.01)$ lower than other treatments or the control group (Table4). The decrease in milk yield may be due to the presence of tannins. 
Kumar and Vaithiyanathan (1990) reported that tannins reduce animals milk yield.

Table 4 :Performance of does during suckling period as affected by dietary Leucaena leaf meal .

\begin{tabular}{|c|c|c|c|c|c|c|c|}
\hline $\begin{array}{l}\text { LLM } \\
\text { Level } \\
(\%)\end{array}$ & $\begin{array}{l}\text { Feed intake } \\
\text { (g/day/doe) }\end{array}$ & $\begin{array}{l}\text { Weight at } \\
\text { kindling } \\
\text { (g/doe) }\end{array}$ & $\begin{array}{c}\text { Weight at } \\
\text { weaning(g/doe) }\end{array}$ & $\begin{array}{c}\text { Body } \\
\text { weight } \\
\text { change }(g)\end{array}$ & $\begin{array}{l}\text { Milk yield } \\
\text { (g/doe) }\end{array}$ & $\begin{array}{c}\text { Total } \\
\text { No. } \\
\text { at birth }\end{array}$ & $\begin{array}{c}\text { No a live } \\
\text { at } \\
\text { weaning }\end{array}$ \\
\hline Control & & $3006 \pm 67.85$ & $2856 \pm 14.10^{a}$ & $-150 . \pm 4.08^{b}$ & & 30 & \\
\hline 15 & $180.5 \overline{ \pm} 0.37^{\mathrm{ab}}$ & $2982 \pm 46.60$ & $281 \overline{7} \pm 8.53^{\mathrm{b}}$ & $-165 \pm 6.45^{a}$ & $2200 \pm 0.041^{b}$ & 2 & 23 \\
\hline 20 & $181.71 \pm 1.11^{a}$ & $3000 \pm 60.27$ & $2843 \pm 5.06^{a}$ & $-157+1.77^{b}$ & $2268 \pm 0.035^{b}$ & $2 \varepsilon$ & 22 \\
\hline 25 & $184.01 \pm 0.73^{a}$ & $3015 \pm 53.78$ & $2845 \frac{+6}{*} .12^{a}$ & $-170_{\star}+4.56^{a}$ & $1910_{\star \pm *} 0.022^{c}$ & 26 & 21 \\
\hline
\end{tabular}

a,b,c,Means in the same column within each classification bearing different letteres, are significantly $(P<0.0)$ deferent.

${ }^{*} \mathrm{p}<0.05 \quad{ }^{* *} \mathrm{p}<0.01$

Ns= not significant

The results indicated that the total number kids born a live and number weaned were decreased with increasing LLM in doe diets (Table 4). The highest total number of kids born and those weaned were shown by does fed on the control, while the lowest records were for does fed diets contained 25\%LLM.

Performance of doe litter

Performance of doe litters as affected by LLM in the diet are presented in Table 5.

Results showed that litter size, litter weight and litter weight gain at birth ,21days and weaning age were generally tended to be lower $(P<0.05)$ with increasing LLM in the diets. It could be noticed that the differences observed in milk output were directly reflected in growth weight of the pups.

The mean pup weights at birth and 21days of lactation, when the young were entirely dependent upon milk are shown in (Table 5).

It is noticed that the lower body weight of pups fed on diet contained $25 \%$ LLM and consequent growth could have been impaired to some extent. Also, It is worthy noting that pregnancy diet had significantly effect on letter size and litter weight at birth. which litter weights and litter size were significantly $(\mathrm{P}<0.05)$ depression for does receiving diet containing $25 \%$ LLM during pregnancy.thes results are nearly similarly to those Reported that by Abdel-Samee,A.M;El-Gendy,K.M and Ibrahim.H; (1994)Who that triplex could replace $25 \%$,as well as acacia leaves could replace $40 \%$ of concentrate in growing, pregnant and lactation NZW rabbit ration in the new reclaimed and desert lands, under subtropical conditions.

Mortality rate of kids during (0-35)days of age was also greater for does received diets contained LLM when compared with control .In the same time the highest mortality rate (21.42) were recorded by doe received diet contained $20 \%$ LLM . Table 5 . shows that the weight gain of litters on each treatment. It should be noted that after culling and cross fostering the litters of does which had been cross fostering the litters of does which had been fed on diet contained LLM during pregnancy were slightly heavier $(P<0.01)$ at the 
Aboul-Ela, S.S. et al.

beginning of lactation as have been improved. suggested by the birth data presented above. Their suckling vig our may therefore, have been improved.

Table 5. Performance of does Litters (Means \pm SE) as affected by leucaena leaf meal levels .

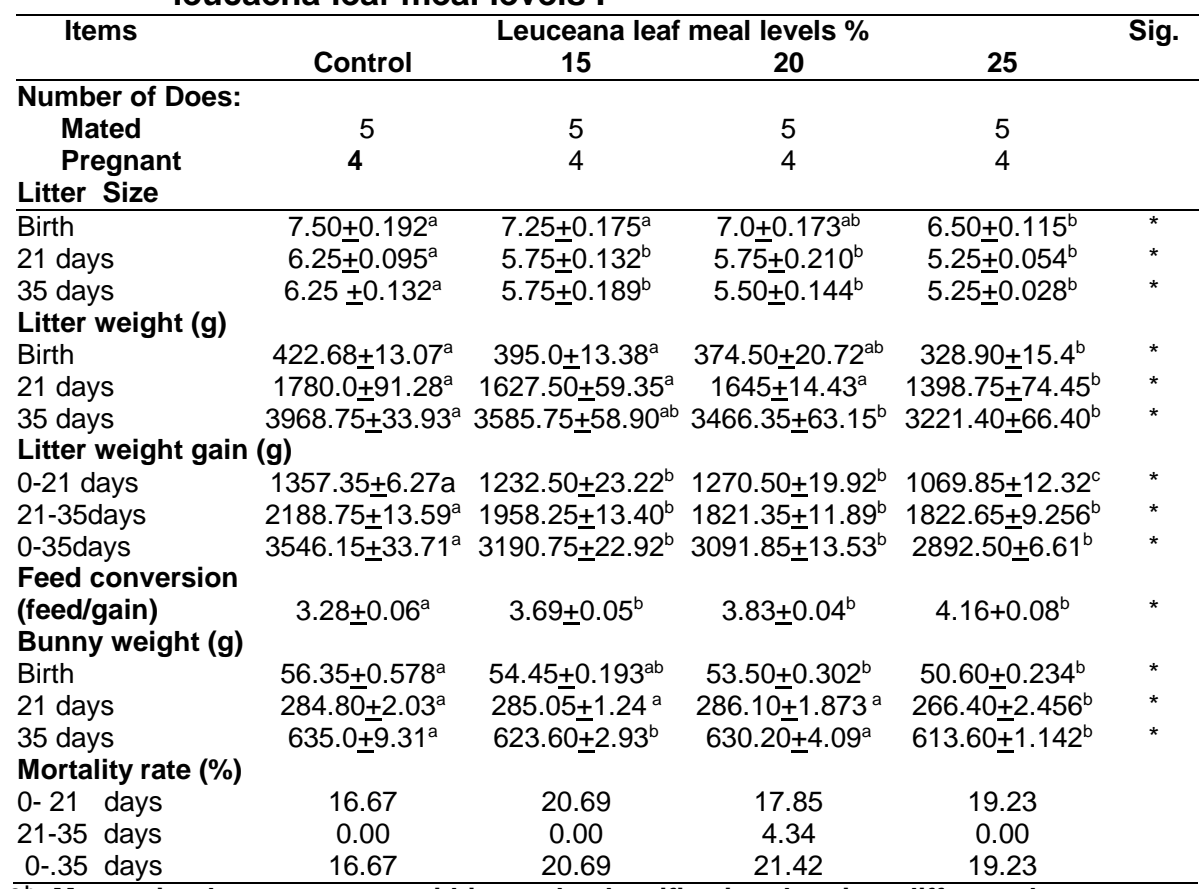

a,b Means in the same row within each classification bearing different letteres are significantly different. Sig.= Significance, ${ }^{*}=(P<0.05)$,

Over the 21days of lactation the gain of litters weight were similar on all treatments containing when compared with control (without LLM) These after, there was a tendency for litter growth to be lower in those does which had received the diets contained LLM during pregnancy.

The diet offered during lactation appeared to have litter influence on letter weight gain.(i.e.milk yield). Feed conversion ratio Table 6 . tended to be higher $(P<0.05)$ by doe rabbits fed LLM diets compared with the control diet. It is clear that feed conversion increased with increasing LLM in the diet from 0 to $25 \%$. The poorest feed conversion was obtained with doe rabbits fed diet contained $25 \%$ LLM., while the better values were recorded for doe fed diet contained $0.0 \%$ LLM followed by those fed 15, 20, and 25\% LLM.The increase in feed conversion ratio may be attributed to the increase in daily feed consumption table 5 .

\section{The digestibility coefficients of the experimental diets}

The Apparent digestibility coefficients of the nutrients and nutritive values of the experimental diets are shown in (Table 6). Increasing the dietary LLM resulted significant $(P<0.05)$ decrease in digestibility coefficients of DM, OM,CP,CF,NFE and feeding values expressed as DCP, TDN \% and 
$\mathrm{DE}(\mathrm{Kcal} / \mathrm{Kg})$. On other hand it increased the digestibility coefficients values of EE was affected by LLM addition.

Table 6 :Digestion coefficients and feeding values (Means+SE)of the experimental diets as affected by dietary Leucaena Leaf Meal levels.

\begin{tabular}{|c|c|c|c|c|c|}
\hline \multicolumn{6}{|c|}{ Leucaena Leaf meal Levels\% } \\
\hline Items & $(0.0)$ & 15 & 20 & 25 & Sig. \\
\hline \multicolumn{6}{|c|}{ Digestibility Coefficients(\%): } \\
\hline Dry matter & $79.10 \pm 0.98^{a}$ & $76.64 \pm 0.22^{b}$ & $74.10 \pm 0.10^{\mathrm{b}}$ & $70.45 \pm 0.48^{b}$ & * \\
\hline Organic matter & $80.85 \pm 0.91^{\mathrm{a}}$ & $77.05 \pm 0.98^{a}$ & $75.38 \pm 0.57^{\mathrm{b}}$ & $72.53 \pm 0.76^{\mathrm{b}}$ & * \\
\hline Crude protein & $77.20 \pm 0.30^{\mathrm{a}}$ & $72.90 \pm 0.39^{\mathrm{a}}$ & $70.88 \pm 0.19^{b}$ & $66.90 \pm 0.10^{\mathrm{b}}$ & ** \\
\hline Crude Fiber & $34.95 \pm 0.66^{a}$ & $32.36 \pm 0.39^{a}$ & $29.25 \pm 0.13^{b}$ & $24.70 \pm 0.05^{\mathrm{b}}$ & ** \\
\hline Ether extract & $75.80 \pm 0.24^{b}$ & $76.58 \pm 0.26^{\mathrm{b}}$ & $79.80 \pm 0.17^{a}$ & $80.05 \pm 0.07^{a}$ & * \\
\hline $\begin{array}{l}\text { Nitrogen Free ext. } \\
\text { Nutritive values: }\end{array}$ & $78.95 \pm 0.21^{\mathrm{a}}$ & $77.52 \pm 0.36^{a}$ & $74.49 \pm 0.42 \mathrm{a}^{\mathrm{b}}$ & $70.33 \pm 0.39^{b}$ & * \\
\hline TDN\% & $54.05 \pm 0.13^{\mathrm{a}}$ & $53.31 \pm 0.21^{\mathrm{a}}$ & $52.88 \pm 0.24 a^{b}$ & $51.27 \pm 0.17^{b}$ & * \\
\hline DCP\% & $13.65+0.07^{a}$ & $13.09+0.06^{\mathrm{a}}$ & $12.71+0.04 a^{b}$ & $12.08+0.09^{b}$ & * \\
\hline $\mathrm{DE}(\mathrm{Kcal} / \mathrm{kg})$ & $2583.85 \pm 60.25^{\mathrm{a}}$ & $2576.86 \pm 50.28^{\mathrm{a}}$ & $2567.45 \pm 45^{\mathrm{ab}}$ & $2498 . \overline{8} 6 \pm 40^{\mathrm{b}}$ & * \\
\hline
\end{tabular}

The decrease in digestibility of nutrients may be due to the presence of tannins, which may adversely affect the nutrition of herbivores through inhibition of digestion as suggested by Robbins et al. (1987). These results were supported with Reed et al. (1990) who reported that tannins may reduce cell wall digestibility by forming indigestible complexes with cell wall carbohydrate. Streeter et al. (1993) found that tannins reduce digestibility of protein and carbohydrate by inhibiting digestive enzymes and by altering permeability of the gut wall. Makkar (2003) postulated that multiple phenolic hydroxyl groups of tannins to formation of complexes primarily with protein and to lesser extent with metal ions, amino acids and polysaccharides.

The present results agree with those obtained by Ghazala et al.(1998) who obtained similar trend when fed LLM to growing rabbits. The reduction in digestibility of nutrients with increasing the dietary LLM level may be due to the increase in dietary Mimosin and Tannin Levels with increasing LLM in the diets.

These substances, however from insoluble complexes with essential minerals, proteins and carbohydrates lowering the nutritive values of the product (Ferket and Middelton,1999).In this respect, Akbar and Gupta (1985), also added that tannin formulate a protein tannin complexes in the gut which results in limiting dietary protein availability. Picard et al.(1987), however presented very low amino acid digestibility values for LLM. Such decrease in nutritive values may be due to the observed decrease in most of nutrients digestibility of these diet.

It is of great importance to note that the results of the digestion trials were coincided generally with performance and feed conversion. 


\section{Economical efficiency}

Results presented in Table7 showed that does fed diets contained $20 \%$ LLM alone decreased the cost of feed relatively to the selling price of total weaned pups and increased considerably the economical efficiency in comparison to the control and other treatments (15 and $25 \%$ LLM in the diets).

These results may be due to the higher number of pups weaned which were given by that does fed diet contained $20 \%$

Table 7. Economic traits of doe rabbits as affected by dietary leucaena leaf meal levels.

\begin{tabular}{lcccc}
\hline \multicolumn{1}{c}{ Items } & \multicolumn{4}{c}{ Leucaena leaf meal levels \% } \\
& Control & $\mathbf{1 5}$ & $\mathbf{2 0}$ & $\mathbf{2 5}$ \\
\hline No of born litters & 30 & 29 & 28 & 26 \\
Total feed consumed (Kg/ doe) & 11.650 & 11.782 & 11.860 & 12.042 \\
Cost of feed consumed (L.E.) & 14.67 & 13.19 & 1257 & 12.40 \\
Total weaned pups( Kg/doe) & 3.968 & 3.586 & 3.467 & 3.222 \\
Selling price of the weaned pups (L.E) & 47.62 & 43.03 & 41.60 & 38.64 \\
Cost of feed/selling price of weaned pups & 32.92 & 29.84 & 29.03 & 26.24 \\
Economical efficiency \% & 224.60 & 226.23 & 230.955 & 217.76 \\
Relative economic efficiency & 100 & 100.73 & 102.84 & 96.95 \\
\hline The prices were $\mathbf{1 2 6 4 , 1 1 2 0 , 1 0 7 0 , 1 0 2 0 , a n d ~ L E / T o n ~ p e l t e d ~ d i e t ~ f o r ~} \mathbf{0 , 1 5 , 2 0}$ and 25\%,
\end{tabular}
respectively. Selling of $1 \mathrm{Kg}$ meat=12 L.E.

In conclusions, From the nutritional and economical efficiency points of view, the leucaena leaf meal could be used up to $20 \%$ in pregnant and lactating rabbit does without deleterious effect on their performance.

\section{REFERENCES}

Abd El-Galil. K.; F.S. Khalil and E.H. El-Ganzoury (2001). Utilization of leucaena leaf Meal By Growing rabbits under the recently reclaimed areas. Egypt. J .Rabbit Sci., 11 (2):151-165.

Abdel Samee, A. M.; K.M . El-Gendy and H. Ibrahim (1994). Rabbit growth and reproductive performance as influenced by feeding desert forage (Acacia Saligna and Atriplex numularia) at North Sinai. Egyptian J. of Rabbit Sci., 4: 25-36.

Akbar, M.A. and P.C. Gupta (1985). Proximate composition tannin and mineral contents of different cultivars of various plant of subabul (Leucaena Leucocephala). Indian J.Anim.Sci.,55:808-812.

A.O.A.C.,(1990).Association of Official Analytical Chemists. Official Methods of Analysis", $15^{\text {th }}$. ed., Washington, USA.

Balbaa,S.I.(1986). Chemistry of crude Drugs-Laboratory manual. Faculty of pharmacy, Cairo University, PP.195.

Cowie, A.T. (1969). Variation in the yield and composition of the milk during lactation in the rabbit and the glactopoietic effect of prolactin. J. of Endocrinology, 44 : 437-450.

D'Mallo, J.P.F and D. Thamas (1978). The composition of leaf meal from leucaena leucocephala. Tropical Sci., 23: 75-78. 
D'Mello, J.P.F. and T. Acamovic (1982). Growth performance of mimosine excretion by young chicks fed on Leucaena Leucocephala. Animal Feed Science and Technology, 7:247-255.

Duncan, D.B. (1955). Multiple range and multiple F test. Biometrics, 11:1-42. National Academy Press, Washington, D.C.

Ferket, P.R. and T. Middelton (1999). Anti nutrients in feedstuffs. Poultry International, 38: $46-55$.

Ghatneker, S.I.; D.C. Auti and V.S. Kamat (1982). Feeding leucaena to Mozambique tilapia and Indian major carps, Proc. of a workship on leucaena Research in the Asian-pacific region in Singapore, 23-26, Nov., 1982, IDRC 81- 83.

Ghazalah.A.A. (1996).Utilization of leucaena leaf meal by layers and effect of tannins and memosine content.Egypt.Poult.Sci.,16:637-655.

Ghazalah, A.A.; A..A. El-Shahat and A.T. El-Yamny (1998). Evaluation of some tropical forage for nutrition and meat production of rabbits. Egypt. J. of Rabbit Sci., 8(2): 127-139.

Goering, H. K. and P.J. Van Soest (1970). Forage Fiber Analyses Agriculture. Handbook. No. 379, Agric. Res. Service, USA.

Gupta, P.C.; V. Sagar and K. Pradhan (1978). Gaur as a feed and fodder crop. Forage Research, 4:109-122.

I.N.R.A. (1984). Institute National de La Recherche Agronomique, L' alimentationes animal monogastriques. Proc., Lapin, Volilles. I.N.R.A., Paris, France.

Kumar, R. and S. Vaithyan (1990). Occurrence, nutritional significance and effect on animal productivity of tannins in tree leaves. J. Animal Feed Sci., Tech., 30:21-38.

Reed, J.D.; H. Soller and A. Woodward (1990). Fodder tree and straw diets for sheep: intake, growth, digestibility and the effects of phenolics on nitrogen utilization. Anim. feed Sci. and Tech. 30: 39-50.

Robbins, C.T.; T.A. Hanely; A.E. Hagerman; O. Hjeljord; D.L Baker; C.C. Schwarty and W.Mauty (1987). Role of tannins in defending plants against ruminants: reduction in protein availability. Ecology, 68:98-107.

Streeter, M.N.; G.M. Hill; D.G. Wagner; F.N. Owens and C.A. Hibberd (1993). Effect of bird resistant and non bird resistant sorghum gain on amino acid digestion by beef heifers. J. Anim. Sci., 71: 1648-1656.

Makkar, H.P. (1993). Antinutintional factors in foods for livestock. Animal production in developing. Countries Occasional publication No 16. Brit. Soci. of Anim. Prod., 69-85.

Makkar, H.P. (2003). Effects and fate of tannins in ruminants animals, adaptation to tannins and strategies to overcome detrimental effects of feeding tannins-rich feeds. J. Small Ruminants Research, 49: 241-256.

Meulen, U.T.; T.Pucher; M.Szyszka and E.A. El-harith (1984). Effect of a dministration of leucaena meal on growth performance and memosine accumulation in growing chicks. Archives fur Geflugelkunde, 48: 41-44.

Partridge, G.G. and S.J.Allan (1983). The effects of dietary protein concentration on the lactational performance of the rabbit. Anim. Prod., $37: 119-123$ 
Perez, J.M.; F.Lebas;T.Gidenne; L.Maertens;G.Xiccato; R.Parigi- Bini; A. Dalla- Zatte;M. Cossu; A. Carazzolo; M . Villamide; R. Carabano; M.J.Ramos; C . Cervera; E . Blas; J . Fernandez- Carmona; E. Falcao; M.L.Cmnha and J . Bengalz Freire;(1995) . European reference method for in vitro determination of diet digestibility in rabbits. World Rabbit Science, $3: 41-43$.

Parige.Bini, R.; G.,Xiccato and M. Cinetto.(1991).Utilizing ripartizione dell, energia e della protina digeribile in coniglie non gravid durante la prima lattazione .Zootecnica Nutrizione Animale 17:107-12.

Picard, M.; H. Angulo ;H.Antoine; C. Bouchot and B. Sauveur (1987).Some feeding strategies for poultry in hot and huProceedings $10^{\text {th }}$ Annual Conference of the Malaysian Society of Animal Production, 110-116.

Raharjo, Y.C ; P.R.Cheeke; N.M.Patton; and Sauveur.B;(1986).Evalution of tropical forages and by- product feeds for rabbit production digestability and effect of heat treatment .Journal of Applied Rabbit research (9) 56-66.

Reddy, C.V.(1999).Improving the nutritional quality of feed .Poultry International,44:36-44.

SAS (1996). Statistical analysis system User's Guide. SAS inst., Cary, NC. USA.

Schiemann, R.; K. Nehrina; L. Hofmann; W. Jentach, and A. Chudy (1972). Energetische Futterbewertung und energienormen, VEB, Deutscher Landwirtschaftsverlag, Berlin, pp 72.

Streeter, M.N.; G.M. Hill; D.G. Wagner; F.N. Owens and C.A. Hibberd (1993). Effect of bird resistant and non bird resistant sorghum gain on amino acid digestion by beef heifers. J. Anim. Sci., 71: 1648-1656.

Yano, C.R.; P.R. Cheeke; M.N. Patton and K. Supriyati (1986). Evaluation of tropical forage and by-product feeds for rabbit production. 1- Nutrient digestibility and effect of heat treatment.. J. App. Rabbit Res., 9 (1): 56- 66.

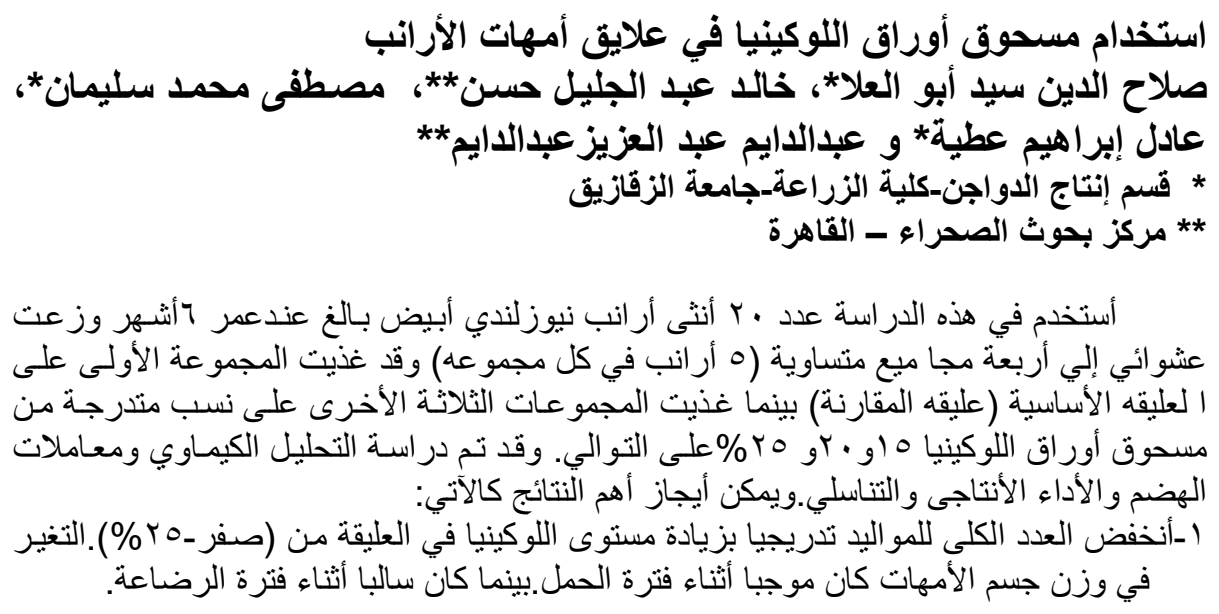


Y ـالغذاء المـأكول مشتملا غذاء الخلفـات زاد بزيـادة مستوى اللوكينيـا في العليقـة من( صـفر إلى (\% ro r-أنتاج اللبن للأمهات لم يتأثر معنويا عند مستوى (صفر و ه او •r\%) ولكن أنخفض معنويـا بزيادة

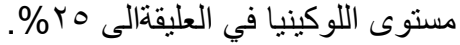

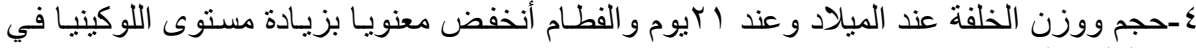

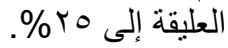
هـ معامل التحويل الغذائي أرتفع معنويا للأر انب المغذاة على مستويات من مسحوق أور اق اللوكينيا مقارنة بالعليقة الأساسية.

7- معاملات هضم المركبات الغذائية والقيم الغذائية انخفضةت معنويـا وذللك بزيـادة مسحوق أوراق

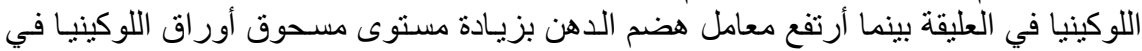
العليقة

V-عليقة الأمهات التي تحتوى على مستوى • r \% من مسحوق أوراق اللوكينيا خفضت نسبيا تكلفة

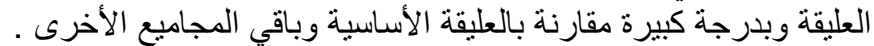

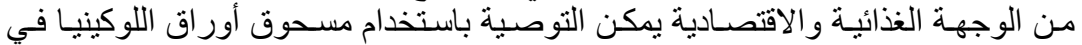

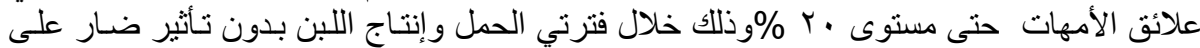
أداء أر انب النيوزيلندي الأبيض . 